\title{
Distribution Intensity and Marketing Utility Perception of Consumers of FMCG Products in Lagos State, Nigeria: Moderating Effect of Channel Multiplicity
}

James A. Adeniran ${ }^{1 *}$

ONIKU, Ayodele 2

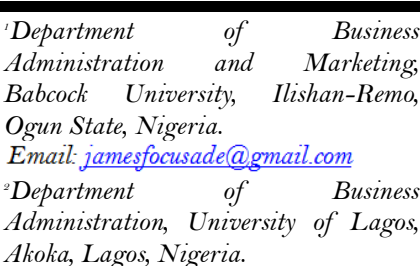

Licensed:

This work is licensed under a Creative Commons Attribution 4.o License.

Keywords:

Distribution intensity

Marketing utility perception

Channel multiplicity.

\begin{abstract}
It has been suggested that a firm should adopt only a few variety of routes to market in order to minimise channel conflicts. But today's consumers which have developed varied and complex choices and preferences for where and how they want to purchase products are continuously forcing FMCGs firms to tailor their channel design and configuration towards multiplicity of channels. Therefore, this study examines the effect of distribution intensity on consumer perception of marketing utility in relation to channel multiplicity. Cross sectional survey research design was adopted for data collection with the aid of a structured and closed ended questionnaire. The questionnaire was administered to 384 consumers across all the local government areas in Lagos. Data was analysed using descriptive and inferential (simple and multiple linear regression analysis) statistics. Findings reveal that distribution intensity has a significant positive effect on marketing utility perception of consumers of FMCGs products in Lagos State, Nigeria. Also, a significant positive relationship was established between distribution intensity and channel multiplicity. Further results show that channel multiplicity has a significant positive effect on marketing utility perception. In a final analysis, the study reveals that distribution intensity and channel multiplicity have a combined effect on marketing utility perception. In concluding, the study gave useful recommendations.
\end{abstract}

\section{Introduction}

In theory, it has been suggested that a firm should adopt only a few variety of routes-to-market in order to minimise channel conflict (Coughlan, Anderson, Stern, \& El-Ansary, 2006).

However, in today's business and marketing environment, customers as part of the external forces that determine channel configuration of firms have developed varied and complex choices and preferences for where and how they want to purchase products. This negates the previous position in theory and provides support for the opinion of Bucklin (1966) on the need for firms to consider varied distribution channels when consumer demand is varied and complex.

In this era of multiplicity of channel through which purchases are made, it is important to understand that consumers have a way of deciding which channel suits them (Valentini, Montaguti, \& Neslin, 2011). This understanding is expected to help managers to adjust channel strategies and practices in order to improve on product availability and customer value through effective multichannel customer management (Neslin et al., 2006).

As a result, many organisations have developed varied and multiple simultaneous channels such as company-owned outlets, owned or outsourced sales force, retailers, call centres, catalogs and web stores (Van Bruggen, Antia, Jap, Reinartz, \& Pallas, 2010). The practices and strategies of multiple channels by FMCG firms have increased consumers' knowledge about choices available to them on how to select, purchase, order, and receive a product or service (Frazier \& Shervani, 1992). However, research has shown that, few firms are effective in practicing and managing multi channel strategies (Myers, Van Metre, \& Pickersgill, 2004; Noble, Shenkan, \& Shi, 2009; Weinberg, Parise, \& Guinan, 2007). 
In Nigeria for example, firms in the FMCGs sector no longer stick to the traditional channel practice where manufacturers deliver bulk to the distributors who in turn are expected to take responsibility for pushing the product down the distribution pipeline to the retailers and from there to the final consumers (Frazierr, Gill, \& Kale, 1989)

Manufacturers now recruit canvassers to help distributors push products in their stores (Onyemah \& Akpa, 2016). FMCGs firms are visibly seen dealing directly with distributors, wholesalers, retailers and in some instances with final consumers who require bulk purchase for special occasions.

The reason for this new trend can be linked to competitive forces, economic forces, technological forces and changing consumers' tastes and preferences of how and where they choose to buy a product (Neslin et al., 2006; Rangaswamy \& Van Bruggen, 2005; Valentini et al., 2011; Van Bruggen et al., 2010; Wallace, Giese, \& Johnson, 2004). In addition, two other reasons that can be linked to the above problem in Nigeria are nonavailability of adequate and reliable market information and inadequate infrastructural facilities (Sule, Ogbadu, \& Achimugu, 2013).

Odupitan (2017) also found that, poor road network is a major infrastructural facility that affects availability of FMCGs products in locations where they are needed in Nigeria, thereby leading to negative marketing utility perception of consumers. The cumulative inventory of unsold goods in the FMCGs sector in Nigeria rose from N1obillion in 2012 to N54.96billion in 2015 (Manufacturer Association of Nigeria [MAN], 2012-2016).

The reasons attached to this large amount of goods as unsold are insecurity, poor road network, etc which suggest that these goods did not reach the places where they are needed - hence the need to measure the perception of consumers as it relates to availability of FMCGs products when and where they are needed.

Gaps were also observed in literature with respect to the focus of existing studies on distribution channels in Nigeria. Some of the existing focus is: distribution of agricultural produce (Imam, Chibok, \& Gamama, 2014); selection of intermediaries by MNC (Ladipo, Alarape, \& Nwagwu, 2013); marketing channels for distribution of consumer products (Liwali, 2013); the effect of distribution on product sales (Obaji, 2011). However, none of these studies worked on distribution intensity with respect to marketing utility perceptions of consumers on FMCGs products, which is the focus of this study.

In view of the above background, the objective of this study is to ascertain the marketing utility perception of consumers of FMCGs products with respect to product availability when and where needed and how channel multiplicity of FMCGs firms influenced this perception.

\section{Literature Review}

\subsection{Distribution Intensity and Marketing Utility Perception}

Distribution intensity has been viewed by different authors in different ways: it is a decision companies make with respect to the number of intermediaries to engage for product distribution at each channel level (Kotler \& Keller, 2009); it is the level of distribution coverage a firm needs to effectively meet customers' needs (Saraf, 2009); it is the degree to which manufacturer limits the number of intermediaries operating within a specific trade area (Fein \& Anderson, 1997; Stern, El-Ansary, \& Coughlan, 1996) defined distribution intensity as the number of intermediaries engaged by manufacturer within its trade area.

In summary, distribution intensity represents the specific stake invested by manufacturer which is aimed at both outgrowing the competition as well as defending trading territories (Coughlan, Erin, Louis, \& ElAnsary, 2001).

The above definitions notwithstanding, the concept of distribution intensity for product marketing covers intensive, selective and exclusive approach (Darkwah, 2016; Kotler \& Keller, 2009; Saraf, 2009; Zikmund \& d'Amico, 2011).

Each of these distribution approaches has been viewed as a policy every manufacturer must put in place regarding product distribution (Agbadudu \& Adekunle, 2017; Kotler \& Keller, 2009). In making this decision, optimal degree of distribution intensity must not be over-looked (Chang \& Tang, 2015) in order to avoid over and under saturation of the market with the product.

This is expected to help in matching manufacturer's capacity with target market's needs in terms of product availability when and where needed (Imam et al., 2014). This can also serve as a basis upon which consumers can form their perception of the marketing utility created through product distribution process.

Viewing it from the perspective of economics, Fripp (2017) defines utility creation in marketing as the range of value and benefits received by consumer from the acquisition and consumption of product. Hassanzoy (2013) in his work on Agricultural Marketing describes it as 'addition of value to farm products as they move from the farm gate to final consumers'.

From this definitions, it is clearer that, marketing process creates utilities (or values) in trying to get the products moved from the point of manufacturing to the final consumers. These values are parts of what is used to stimulate desirability from the consumers toward the products.

A firm goes through the process of both producing and distributing a product to create utility (value) for the final consumer Fripp (2017). Going by the thought of the institutional school of marketing theory which focuses on the role of various organisations that operate within the distribution channel for a product or 
service (Winsor, Sheth, \& Manolis, 2004) utilities created through the engagement of intermediaries and multiple channels in marketing activities can be considered as one of the measures of organisational performance and customer satisfaction in the fast moving consumer goods industry. Economists have also generally showed that value-added-resellers are providing time, place, possession, or form utility to consumers (Macklin, 1924; Weld, 1916).

In another line of thought, Ellis and Jacobs (1977) were of the opinion that, three out of the four traditional categories of utilities (form, place and time) are physical activities associated with making, moving and storing the product while possession utility is concerned with psychological satisfaction.

Empirically, studies on distribution intensity have been carried out across countries and industries, Agbadudu and Adekunle (2017) focus on FMCGs in Nigeria; Bucklinn, Siddarth, and Silva-Risso (2008) focus on automobile in the USA; Frazier and Lassar (1996) focus on consumer electronics in the USA; Gitobu (2004) focus on pharmaceuticals in Kenya; Liu, Huang, and Lin (2009) focus on electronics in Taiwan.

Findings from the studies of Agbadudu and Adekunle (2017) and Frazier and Lassar (1996) show that there are varieties of predictors of distribution channel intensity for consumers good which include: product positioning objective of producers; their target market; quality of retailers required; the level of support the manufacturers are prepared to give to retailer; brand quality; level of firm's technological advancement.

On the other hand, Bucklinn et al. (2008) found that, buyers were more likely to select cars based on dealer networks that had shorter distances to the closest outlets (accessibility); more dealers within a given radius from buyers (concentration); and locations that skewed toward buyers (spread). Result of one of the hypotheses tested by Liu et al. (2009) shows that, engaging in distribution intensity have a strong and positive effect on gaining market share.

Moreover, Gitobu (2004) found that most pharmaceutical firms in Kenya practice intensive distribution using factors such as product, market and consumer characteristics except for a few with high end prescription products which practice selective distribution intensity.

Aila et al. (2011) examine the impact of multinational channel strategy on customer value from the perspective of customer demand using major distributors of the Coca Cola company in Western Kenya and found that stock availability is significant in determining customer value and showed a high positive and significant correlation between stock availability and sales while on the contrary the study by Geersbro and Vedel (2008) which focus on the perceived buyer value of intermediated channels in the Danish building material industry found that, the intermediaries in the industry studied lacked value creation skills. In view of this, the hypothesis one below is proposed for this study.

$\mathrm{H}_{01}$ : Distribution intensity has no significant effect on marketing utility perception of consumers of FMCGs in Lagos State, Nigeria.

\subsection{Distribution Intensity and Channel Multiplicity}

The review of the concept and existing empirical studies on distribution intensity and measures of marketing utilities that go along the distribution pipeline as given above suggests that, this study cannot be concluded without considering how advancement in information technology and changing consumer needs for channel service output is dramatically affecting the routes to market in the fast moving consumer good $s$ sector (Van Bruggen et al., 2010). In addition, Hibbard, Kacker, and Sadeh (2017) are of the opinion that, growth in competition is another strong reason for firms to embrace the practices of channel multiplicity in order to drive both performance and customer delight.

Having established the need and basis for the practices of channel multiplicity as a way of achieving effective distribution intensity, it is important to provide better understanding of the concept of channel multiplicity.

This concept encompasses the creation of multiple independent channels by firms which can be used to attend to the information needs, delivery needs, facilitation needs, post-purchase needs of the consumers with respect to products and services offered with the aim of delivering customer satisfaction and retention (Nunes \& Cespedes, 2003; Van Bruggen et al., 2010).

These channels have been developed by many organisations in form of multiple simultaneous channels such as company-owned outlets, owned or outsourced sales force, retailers, call centres, catalogs and web stores (Van Bruggen et al., 2010) which boost consumers' knowledge about choices available to them on how to select, purchase, order, and receive a product or service (Frazier \& Shervani, 1992).

Distribution intensity in the environment of channel multiplicity can be related to the concept of channel expansion which involves increase in intensity of distribution within an existing channel and addition of new distribution channels (Homburg, Vollmayr, \& Hahn, 2014; Jindal, Reinartz, Krafft, \& Hoyer, 2007; Van Bruggen et al., 2010).

In relating distribution intensity to channel multiplicity, consumers' heart share, brand awareness and product quality were used to measure consumer perception of the relationship between the two concepts in previous studies (Liu et al., 2009). 
Consumer heart share is the percentage of customers who choose a brand based on emotional relationship with the brand product, retailers or service providers (Day, 1989; Kotlers, Swee, Siew, \& Chin, 2003). When few intermediaries are engaged, it can limit a brand's level of exposure in the market place while too many intermediaries on the other hand can be harmful to the perception of brand exclusivity (Frazier \& Lassar, 1996).

Yoo, Donthu, and Lee (2000) in an examination of selected marketing mix element and brand equity found that, perceived quality of a brand is positively related to the extent to which the brand is available in stores. Also, distribution intensity may not equally be effective for all firms in terms of consumer heart share (Liu et al., 2009).

Firms with low brand awareness can increase consumer heart share by increasing distribution intensity while increasing distribution intensity may not be that effective for firms with high brand awareness. In a study on the asymmetric effect of distribution intensity on marketing performance by Liu et al. (2009), the hypothesis which positively relates consumer heart share to a firm's distribution intensity showed a negative coefficient of interaction after data analysis particularly when brand awareness is high.

$\mathrm{H}_{\mathrm{o} 2}$ : Distribution intensity has no significant positive relationship with channel multiplicity for FMCGs products in Lagos State, Nigeria.

$\mathrm{H}_{\text {os }}$ : Channel multiplicity has no significant effect on marketing utility perception of consumers of FMCGs in Lagos State, Nigeria.

$\mathrm{H}_{\mathrm{o} 4}$ : Distribution intensity and channel multiplicity have no significant combined effect on marketing utility perception of consumers of FMCGs in Lagos State, Nigeria.

\section{Theoretical Review}

This study is anchored on the Transaction Cost Economic Theory. The two major scholars linked to the development of transaction cost economics theory are Coase (1937) and Williamson (1979).

Coase contends that whether certain economic tasks are performed by the firm or through others in the market, costs are incurred. Williamson was the first to discuss the theory in the context of decision by a firm whether to do something internally or to outsource (make or buy decision). Transaction cost economics theory is one among the various theories of corporate governance structure. However, the focus is not the protection of the ownership rights of shareholders, rather, the effective and efficient ways of carrying out transactions by firms.

The theory argued that, a firm governance structure or control will depend on whether its economic transactions are internalized or sourced from external parties. It focused on how firms coordinate their economic transactions through make or buy arrangement (Joskow, 1988). This suggests that, governance structure of a firm should be within the boundaries of how it gets tasks done (Holmstrom \& Roberts, 1998; Williamsonn, 2005; Williamsons, 2002).

Transaction costs depend on how the transaction is organised. When it occurs within an organisation, transaction cost can include managing and monitoring personnel and procuring inputs and capital equipment. But if it is organised from an external provider, costs include search and information, contract management and performance monitoring.

In summary, Williamsone (1975) identified three determinants of transaction cost: inability to foresee all future situations in the contracting moments; opportunism that exists when one of the partners pursues self interest; and cost that will be incurred if production assets are redeployed to another use.

By relating the focus of this theory to the scope of this study, FMCGs firms must be able to effectively address the need of customers through distribution intensity without losing focus of cost efficiency and profitability while reaching the target market through various channels.

In order to achieve this, FMCGs firms may have to adopt a strategy that can minimise marketing cost and maximise customer satisfaction and perception of the process of making products available when and where they are needed. Arguments have been advanced to present transaction cost economics theory as a core theory of strategy (Williamsony, 1991).

On the notion that this theory is focused on minimizing transaction costs, Ciborra (1993) was the first author to use it to explain the design of computer based information system as a solution that can be used to reduce transaction costs of firms.

This can also be a basis for FMCGs firms to embrace online distribution system which will be less costly to both the firms and the customers of their products. The theory was also built on the foundation that it can help to check the act of opportunism where certain services are to be outsourced by ensuring necessary search and agreement is put in place to guide behaviours. Gerdoci, Skreli, and Imami (2015) anchored their study on relational governance among farmers and buyers in the apple sector in Albania on transaction cost economics theory to minimise acts of opportunism. 


\section{Methodology}

Cross sectional survey research design was adopted for the study. This method is suitable for selecting sample from large population and it aids data collection across different locations (Kalubanga, Tumwebaze, \& Kakwezi, 2012; Ladipo et al., 2013; Oko, 2013) such as the case for this study in Lagos State which has many local government areas.

The study population was based on the estimated finite population of Lagos State (12,550,598) as published by the National Population Commission (NPC) and National Bureau of Statistics (NBS) in 2016 (National Bureau of Statistics, 2016). This provided a verifiable number of people from which sample was drawn for this study (Kalubanga et al., 2012; Sarkar \& Pareek, 2012). Using the Krejcie and Morgan (1970) sample size table, sample size for the study was 384 .

The purposive sampling technique was adopted to identify the sample. This method helped in selecting the categories of consumers which the researcher considered suitable in terms of age bracket, ability to read and write, and which have at least one source of income.

The convenience method was used to reach out to the sample in work places, shopping malls, homes and the neighbourhood. Questionnaire with structured and closed ended questions was used as the research instrument. This aided proper coordination of responses and easy collection of data for this study. The study instrument comprised of two main sections: section A, demographic section and section B, study variables section. Section B has questions for measuring the three variables covered under the topic.

A six Likert scales ranging 6 for strongly agree and 1 for strongly disagree was adopted for the questionnaire response options. Descriptive statistics, correlation, simple linear regression and multiple regression were used as methods of data analysis with the aid of SPSS 23.0 version. Content and construct validity were conducted on the instrument and reliability test with the following results:

Table-4.1. Results of Reliability and Validity Tests.

\begin{tabular}{c|c|c|c|c|c}
\hline Variables & \multirow{2}{*}{$\begin{array}{c}\text { Number } \\
\text { of items }\end{array}$} & Reliability Results & \multicolumn{2}{|c}{ Validity Results } \\
\cline { 3 - 7 } & Cronbach Alpha & KMO & Bartlett's Test & Sig. \\
\hline Distribution Intensity & 5 & 0.787 & 0.611 & 39.357 & 0.000 \\
\hline Marketing Utility Perception & 5 & 0.838 & 0.656 & 49.257 & 0.000 \\
\hline Channel Multiplicity & 6 & 0.728 & 0.596 & 37.296 & 0.001 \\
\hline
\end{tabular}

Source: Researcher's Computation (2018).

Table-5.1. Descriptive Statistics

\begin{tabular}{|c|c|c|c|c|}
\hline $\mathbf{S} / \mathbf{N}$ & Description & $\mathbf{N}$ & Mean & Std. Deviation \\
\hline DI.1 & $\begin{array}{l}\text { Detergent, toothpaste, beverage products, etc are sold in wholesale and retail } \\
\text { stores across Lagos State. }\end{array}$ & 347 & 5.76 & 0.425 \\
\hline DI.2 & $\begin{array}{l}\text { Adequate number of sales outlets for detergent, toothpaste, beverage products, etc } \\
\text { exists in Lagos State. }\end{array}$ & 347 & 5.34 & 0.627 \\
\hline DI.3 & $\begin{array}{l}\text { Sales outlets selling detergent, toothpaste, beverage products, etc are closer to } \\
\text { customers across Lagos State. }\end{array}$ & 347 & 5.18 & 0.856 \\
\hline DI.4 & $\begin{array}{l}\text { Detergent, toothpaste, beverage products, etc are sold on every street across } \\
\text { Lagos State. }\end{array}$ & 347 & 5.00 & 1.169 \\
\hline DI.5 & $\begin{array}{l}\text { Detergent, toothpaste, beverage products, etc are sold in open air market across } \\
\text { Lagos State. }\end{array}$ & 347 & 5.24 & 0.734 \\
\hline MUP.1 & $\begin{array}{l}\text { Detergent, toothpaste, beverage products, etc are available to buy anywhere in } \\
\text { Lagos State. }\end{array}$ & 347 & 5.15 & 0.970 \\
\hline MUP.2 & $\begin{array}{l}\text { Detergent, toothpaste, beverage products, etc are available to buy anytime in } \\
\text { Lagos State. }\end{array}$ & 347 & 4.69 & 1.137 \\
\hline MUP.3 & $\begin{array}{l}\text { Detergent, toothpaste, beverage products, etc are available in affordable sizes in } \\
\text { Lagos State. }\end{array}$ & 347 & 5.14 & 0.706 \\
\hline MUP.4 & $\begin{array}{l}\text { Detergent, toothpaste, beverage products, etc are available at sales outlets in } \\
\text { Lagos State for pay and take home. }\end{array}$ & 347 & 5.33 & 0.928 \\
\hline MUP.5 & $\begin{array}{l}\text { Customers do not travel long distance to buy detergent, toothpaste, beverage } \\
\text { products, etc in Lagos State. }\end{array}$ & 347 & 5.14 & 0.875 \\
\hline CM.1 & $\begin{array}{l}\text { Online channels are provided by manufacturers for information about detergent, } \\
\text { toothpaste, beverage products, etc in Lagos markets. }\end{array}$ & 347 & 4.75 & 1.176 \\
\hline CM.2 & $\begin{array}{l}\text { Locations are provided by manufacturers for information about detergent, } \\
\text { toothpaste, beverage products, etc in Lagos markets. }\end{array}$ & 347 & 4.27 & 1.445 \\
\hline CM.3 & $\begin{array}{l}\text { Information about sales outlets for detergent, toothpaste, beverage products, etc is } \\
\text { provided by manufacturers in Lagos State. }\end{array}$ & 347 & 4.45 & 1.292 \\
\hline CM.4 & $\begin{array}{l}\text { Platforms for customers to make comments after usage of detergent, toothpaste, } \\
\text { beverage products, etc are provided by manufacturers in Lagos State. }\end{array}$ & 347 & 4.42 & 1.224 \\
\hline CM.5 & $\begin{array}{l}\text { Buyers of detergent, toothpaste, beverage products, etc in Lagos State have the } \\
\text { option of buying online. }\end{array}$ & 347 & 4.04 & 1.452 \\
\hline CM.6 & $\begin{array}{l}\text { Buyers of detergent, toothpaste, beverage products, etc in Lagos State only have } \\
\text { the option of buying in stores. }\end{array}$ & 347 & 3.95 & 1.649 \\
\hline
\end{tabular}

Source: Field Results (2018). 


\section{Results}

\subsection{Demographic Characteristics of Respondents}

Results of analysis of the demographic data of respondents show the following: $48.4 \%$ represents male while $51.6 \%$ were female; $66.6 \%$ were between 18 -30years, $25.6 \%$ were between $31-40 y e a r s$ while $7.8 \%$ represents age bracket $41-5$ Oyears; $8.4 \%$ of the respondents were holders of SSCE certificate, $14.1 \%$ ND/NCE while $77.5 \%$ were holders of first degree and post-graduate certificates; $67.4 \%$ of the respondents were single while $32,6 \%$ were married. The implications of these results showed that all the respondents were adult, with basic educational qualifications and matured and possessed requisite level of understanding to participate in the consumer survey.

The results of reliability test ranged between $0.7-0.8$ which shows that all the items attained the recommended threshold of 0.7 (Bhatnagar, Kim, \& Many, 2014; Nunnally, 1978). Moreover, factor analysis results for the construct validity showed that KMO value for all the variables are more than 0.5 recommended threshold (Kaiser, 1974) with Bartlett's Test of Sphericity for all the variables statistically significant at 0.000. This indicates that the study instrument was valid.

Table-5.2. Results of linear regression analysis on effect of distribution intensity on marketing utility perception of consumers of FMCGs products in Lagos state, Nigeria.

\begin{tabular}{|c|c|c|c|c|c|c|}
\hline \multicolumn{7}{|c|}{ Coefficients } \\
\hline \multirow{2}{*}{\multicolumn{2}{|c|}{ Model }} & \multicolumn{2}{|c|}{ Unstandardized Coefficients } & \multirow{2}{*}{$\begin{array}{l}\text { Standardized } \\
\text { Coefficients } \\
\text { Beta }\end{array}$} & \multirow[t]{2}{*}{$\mathrm{T}$} & \multirow[t]{2}{*}{ Sig. } \\
\hline & & $\mathrm{B}$ & Std. Error & & & \\
\hline & (Constant) & 2.414 & 1.199 & & 2.013 & .045 \\
\hline & $\begin{array}{l}\text { Distribution } \\
\text { Intensity }\end{array}$ & .868 & .045 & .720 & 19.296 & .000 \\
\hline
\end{tabular}

$\mathrm{R}=0.720 ; \quad \mathrm{R}^{2}=0.519 ; \mathrm{T}=19.296, \mathrm{~F}=372.330, \mathrm{p}<0.05$

Dependent Variable: Marketing Utility Perception.

Source: Field Result (2018)

Table 5.2 shows the results of a regression analysis that was performed in order to determine the effect of distribution intensity on marketing utility perception of consumers of FMCGs products in Lagos state, Nigeria. The results reveal that distribution intensity has a significant positive effect on marketing utility perception of consumers of FMCGs products in Lagos state, Nigeria $(\beta=0.868, \mathrm{t}=19.296, \mathrm{~F}=372.330$, $\mathrm{p}<0.05)$. The result also shows that $51.9 \%$ of the variations in marketing utility perception of consumers of FMCGs products in Lagos State, Nigeria is explained by distribution intensity $\left(\mathrm{R}^{2}=0.519\right)$ which is statistically significant. The P-value of 0.000 implies that the regression of distribution intensity on marketing utility perception of consumers of FMCGs products in Lagos State, Nigeria is statistically significant at $\mathrm{p}<0.05$. Therefore, the null hypothesis one $\left(\mathrm{H}_{01}\right)$ which states that distribution intensity has no significant effect on marketing utility perception of consumers of FMCGs products in Lagos state, Nigeria is rejected.

Table-5.3. Result of correlations between distribution intensity and channel multiplicity.

\begin{tabular}{|c|c|c|c|}
\hline & & DI & $\mathbf{C M}$ \\
\hline \multirow[t]{3}{*}{$\mathrm{DI}$} & Pearson Correlation & 1 & $.317^{\text {*** }}$ \\
\hline & Sig. (2-tailed) & & .000 \\
\hline & $\mathrm{N}$ & 347 & 347 \\
\hline \multirow[t]{3}{*}{$\mathrm{CM}$} & Pearson Correlation & $.317^{\text {*** }}$ & 1 \\
\hline & Sig. (2-tailed) & .000 & \\
\hline & $\mathrm{N}$ & 347 & 347 \\
\hline
\end{tabular}

The result $\mathrm{R}$ in Table 5.3 signifies the degree of relationship that exists between distribution intensity and channel multiplicity for FMCGs products in Lagos State, Nigeria. From the above table R $=0.317$ which indicates that a significant positive relationship exist between distribution intensity and channel multiplicity for FMCGs products in Lagos State, Nigeria at $\mathrm{P}<0.01$. Therefore, the null hypothesis two $\left(\mathrm{H}_{02}\right)$ which states that distribution intensity has no significant positive relationship with channel multiplicity for FMCGs products in Lagos state, Nigeria is rejected. 
Table-5.4. Results of linear regression analysis on effect of channel multiplicity on marketing utility perception of consumers of FMCGs products in Lagos state, Nigeria.

\begin{tabular}{|c|c|c|c|c|c|c|}
\hline \multicolumn{7}{|c|}{ Coefficients } \\
\hline \multirow{2}{*}{\multicolumn{2}{|c|}{ Model }} & \multicolumn{2}{|c|}{$\begin{array}{l}\text { Unstandardized } \\
\text { Coefficients }\end{array}$} & \multirow{2}{*}{$\begin{array}{l}\text { Standardized } \\
\text { Coefficients } \\
\text { Beta }\end{array}$} & \multirow[t]{2}{*}{$\mathbf{T}$} & \multirow[t]{2}{*}{ Sig. } \\
\hline & & B & $\begin{array}{l}\text { Std. } \\
\text { Error }\end{array}$ & & & \\
\hline & (Constant) & 16.988 & .888 & & 19.123 & .000 \\
\hline & $\begin{array}{l}\text { Channel } \\
\text { Multiplicity }\end{array}$ & .326 & .034 & .461 & 9.661 & .000 \\
\hline
\end{tabular}

Dependent Variable: Marketing Utility Perception.

Source: Field Result (2018).

Table 5.4 shows the results of a regression analysis that was performed in order to determine the effect of channel multiplicity on marketing utility perception of consumers of FMCGs products in Lagos state, Nigeria. The results reveal that channel multiplicity has a significant positive effect on marketing utility perception of consumers of FMCGs products in Lagos state, Nigeria $(\beta=0.326, \mathrm{t}=9.661, \mathrm{~F}=93.341, \mathrm{p}<0.05)$. The result also shows that $21.3 \%$ of the variations in marketing utility perception of consumers of FMCGs products in Lagos State, Nigeria is explained by channel multiplicity $\left(\mathrm{R}^{2}=0.213\right)$ which is statistically significant. The Pvalue of 0.000 implies that the regression of channel multiplicity on marketing utility perception of consumers of FMCGs products in Lagos State, Nigeria is statistically significant at $p<0.05$. Therefore, the null hypothesis three $\left(\mathrm{H}_{03}\right)$ which states that channel multiplicity has no significant effect on marketing utility perception of consumers of FMCGs products in Lagos state, Nigeria is rejected.

Table-5.5. Multiple regression results for the combined effect of distribution intensity and channel multiplicity on marketing utility perception of consumers of FMCGs products in Lagos state, Nigeria.

\begin{tabular}{|c|c|c|c|c|c|c|}
\hline \multicolumn{7}{|c|}{ Coefficients } \\
\hline \multirow{2}{*}{\multicolumn{2}{|c|}{ Model }} & \multicolumn{2}{|c|}{ Unstandardized Coefficients } & \multirow{2}{*}{$\begin{array}{l}\text { Standardized } \\
\text { Coefficients } \\
\text { Beta }\end{array}$} & \multirow[t]{2}{*}{$\mathrm{T}$} & \multirow[t]{2}{*}{ Sig. } \\
\hline & & $\mathrm{B}$ & Std. Error & & & \\
\hline & (Constant) & .296 & 1.163 & & .255 & .799 \\
\hline & $\begin{array}{l}\text { Distribution } \\
\text { Intensity }\end{array}$ & .769 & .044 & .638 & 17.312 & .000 \\
\hline & $\begin{array}{l}\text { Channel } \\
\text { Multiplicity }\end{array}$ & .183 & .026 & .259 & 7.025 & .000 \\
\hline
\end{tabular}

$\mathrm{R}=0.761 ; \mathrm{R}^{2}=0.579 ; \mathrm{Adj} . \mathrm{R} 2=0.577 ; \mathrm{F}=236.935, \mathrm{p}<0.05$

Dependent Variable: Marketing Utility Perception.

Source: Field Result (2018).

Table 5.5 shows the results of multiple regression analysis used to evaluate the combined effect of distribution intensity and channel multiplicity on marketing utility perception of consumers of FMCGS products in Lagos state, Nigeria. The regression results show that the coefficient of R squared of 0.579 implies that the study variables could explain $57.9 \%$ variations in the marketing utility perception of consumers of FMCGs products in Lagos state, Nigeria. The R squared and adjusted R squared is high, and implied that there is a high variation that can be explained by the model. The overall model is statistically significant $(\mathrm{F}=$ 236.935, p<0.05). This implies that the regression of distribution intensity and channel multiplicity on marketing utility perception of consumers of FMCGs products in Lagos State, Nigeria is statistically significant at $\mathrm{p}<0.05$. Therefore, the null hypothesis four $\left(\mathrm{H}_{04}\right)$ which states that distribution intensity and channel multiplicity have no significant combined effect on marketing utility perception of consumers of FMCGs products in Lagos state, Nigeria is rejected.

\section{Discussion of Findings}

The results of hypothesis one $\left(\mathrm{H}_{01}\right)$ which show that distribution intensity has a significant positive effect on marketing utility perception of consumers of FMCGs products in Lagos State, Nigeria is consistent with the findings of Bucklinn et al. (2008) who study distribution intensity and new car choice in the automobile industry in U.S. and found that buyers were more likely to select cars based on dealer networks that had shorter distances to the closest outlets (accessibility); based on more dealers within a given radius from buyers (concentration); and based on locations that skewed toward buyers (spread). Results of hypothesis one also find support from the work of Liu et al. (2009) which reveals that engaging in distribution intensity has a strong and positive effect on gaining market share. Additional support was found for the results from Aila et al. (2011) who examine the impact of multinational channel strategy on customer value from the perception of customer demand from major distributors of the coca cola company in Western Kenya and find that stock 
availability which is the essence of distribution intensity was significant in determining customer value (marketing utility perception). The descriptive statistics results of DI $(\mathrm{M}=5.30, \mathrm{SD}=0.762)$ and MUP $(\mathrm{M}=5.09, \mathrm{SD}=0.923)$ in Table 5.1 and R-Squared in Table $5.2(51.9 \%)$ is an indication of the extent to which consumers of FMCGs products in Lagos State perceived marketing utility as being delivered through the distribution intensity of FMCGs firms in the State.

Results of hypothesis two $\left(\mathrm{H}_{02}\right)$ revealed that there is a significant positive relationship between distribution intensity and channel multiplicity. However, the relationship signifies a weak one. The implications of this is that, distribution intensity efforts of FMCGs firms in Lagos State is only geared more toward physical product availability than also providing additional channels that will help to meet other needs of the consumers, particularly information, search and post-purchase needs. This is also reflected in the results of the descriptive statistics in Table 5.1 where all the mean results for DI were 5.0 and above and the mean results for $\mathrm{CM}$ were all below 5.0. This result, which further signifies that there is a low emotional relationship between a brand and consumers' choice reveals a low brand awareness as well as low consumer heart share (Liu et al., 2009).

Results of hypothesis three $\left(\mathrm{H}_{03}\right)$ showed that channel multiplicity has a significant positive effect on marketing utility perception of consumers of FMCGs products in Lagos State, Nigeria. Despite this, the perception of respondents with respect to the creation and use of multiple channels that gives consumers room to make choice of how and where they prefer to make purchase signifies that FMCGs firms in Lagos State need to pay attention to the practices of channel multiplicity as indicated in Table 5.1 for $\mathrm{CM}(\mathrm{M}=4.31$, $\mathrm{SD}=1.373$ ).

Results of hypothesis four $\left(\mathrm{H}_{04}\right)$ revealed that, distribution intensity and channel multiplicity have a significant positive effect on marketing utility perception of FMCGs products in Lagos State, Nigeria. The implication of this is that, combining distribution intensity with channel multiplicity can significantly influence the way consumers of FMCGs products in Lagos State perceive the utility created by the distribution and marketing process of FMCGs firms in the State. This is better explained by the high degree of relationship between the three variables $(\mathrm{R}=0.761)$ and the extent of the variations in MUP caused by DI and $\mathrm{CM}$.

\section{Implications of Findings}

The implications of findings of the study are presented as they concern management of FMCGs firms, the FMCGs industry and the Buying public (society).

The findings gave support to positions in literature regarding the concepts examined in the study. The implication of this to Management of FMCGs firms in Lagos State, Nigeria is that, attention should be given to the constructs used in this study which show that distribution intensity has a significant positive effect on marketing utility perception of consumers of FMCGs products. This can be done through allocation of more resources to the practices that promote distribution intensity and that can help to give consumers the perception of availability of FMCGs product when and where they are needed. This will help to create brand awareness, consumer emotional attachment to brands which in turn can lead to higher consumer heart share and market share for the firms. The results also point to the fact that, customers' channel needs are evolving and that Management of FMCGs firms must take note of this as a critical driver of channel multiplicity development as well as basis for shifts that are occurring in routes to market, customer interactions and value creation.

The findings of the study, no doubt, also have implications for the FMCGs industry in Nigeria. Consumer survey is a major way to measure how the market responds to a firm's product and marketing activities. Since this study focused on the perception of consumers, the results are pointers to firms in the FMCGs industry to check their distribution intensity strategies and practices against those considered in the study and use the areas of differences to close gaps for further growth and development of the sector. The study also provides a basis for trade associations and chambers of commerce and industry that have FMCGs firms as their members to consider some of the findings and recommendations for the purpose of improving on industry practices and contributions to national GDP.

One of the implications of the findings is that, it will help consumers and the larger society to develop confidence in the ability of FMCGs firms in the country with respect to availability of FMCGs goods when and where and in the quantity they are needed.

\section{Recommendations}

In view of the findings of the study, it is recommended that FMCGs firms should carry out market and consumer survey regularly to measure the extent of consumers' perception with respect to the utilities created in the process of product distribution and marketing.

The aspect of channel multiplicity that cater for the information need, delivery need, facilitation need and post-purchase needs of the consumers should be considered by FMCGs firms since these are expected to have significant positive effect on consumers' perception of marketing utility. The results provided a basis to recommend to FMCGs firms to consider the scope of channel multiplicity covered in the study as distribution 
approaches that can help boost the double-edged results of distribution intensity (i.e. consumer delight and increased market share).

\section{Limitations and Suggestions for Further Studies}

The study was limited to the perception of consumers in Lagos State. There is need for future researcher to extend to the perception of FMCGs firms as well as a combined study of the perception of both the consumers and the firms.

The concept and scope of channel multiplicity covered in the study need to be studied in more locations, particularly as it relates to FMCGs products. Measurement of the perception of consumers with respect to value creation and the effect on market share and other measures of organisation performance can be the focus of future research.

\section{Conclusion}

In view of the findings, it can be concluded that distribution intensity is a predictor of marketing utility perception of consumers of FMCGs products in Lagos State, Nigeria, and that these value perceptions can further be enhanced with channel multiplicity. In other words, the study shows that, the combination of distribution intensity and channel multiplicity can have significant positive effect on value perception of consumers of FMCGs products.

\section{References}

Agbadudu, J. E., \& Adekunle, S. A. (2017). Distribution Channel Intensity Among Table Water Producers In Nigeria. Oradea Journal of Business and Economics, 2(2), 56-66.

Aila, F. O., Mumbo, H., Odera, O., Ondiek, G., Mise, J. K., \& Owaga, E. (2011). Multinational channel strategy and customer value in an emerging economy. Australian Journal of Business and Management Research, 1(9), 98-104.

Bhatnagar, R., Kim, J., \& Many, J. E. (2014). Candidate surveys on program evaluation: Examining Instrument reliability, validity and program effectiveness. American Journal of Educational Research, 2(8), 683-690.

Bucklin, L. P. (1966). A theory of distribution channel structure. Berkeley, California: University of California, Institute of Business.

Bucklinn, R. E., Siddarth, S., \& Silva-Risso, J. M. (2008). Distribution intensity and new car choice. Retrieved from https://archive.ama.org/archive/AboutAMA/Pages/AMA\%20Publications/AMA\%20Journals/Journal\%20of\% 20Marketing\%20Research/TOCs/summary\%20aug\%2008/DistributionIntensity_jmrAug08.aspx. [Accessed, $2 / 1 / 2018]$.

Chang, S., \& Tang, Y. (2015). Exploring heterogeneity of distribution intensity: Evidence from emerging market entry experience with benchmark brands in China. Asian Journal of Research, 5(1), 1-15.

Ciborra, C. U. (1993). Teams markets and systems. Cambridge: Cambridge University Press.

Coase, R. (1937). The nature of the firm. Economica, 4(16), 386-405.

Coughlan, A. T., Anderson, E., Stern, L. W., \& El-Ansary, A. I. (2006). Marketing channels (7th ed.). Upper Saddle River, NJ: Prentice Hall.

Coughlan, A. T., Erin, A., Louis, W. S., \& El-Ansary, A. (2001). Marketing channels (6th ed.). Upper Saddle River, NJ: Prentice Hall.

Darkwah, L. K. (2016). Sales and distribution networks of fast moving consumer goods (FMCGs) companies in Ghana: A case study of selected companies in the Kumasi metropolis. Retrieved from http://ir.knust.edu.gh/bitstream/123456789/10329/1/LEROY\%20KWADWO\%2ODARKWAH\%20JUNIOR.p df. [Accessed, 16/5/2018].

Day, E. (1989). Share of heart: What is it and how can it be measured? The Journal of Consumer Marketing, 6(1), 5-12.

Ellis, D. S., \& Jacobs, L. W. (1977). Marketing utilities: A new look. Journal of the Academy of Marketing Science, 5(1), 2 1-26.

Fein, A. J., \& Anderson, E. (1997). Patterns of credible commitments: Territory and brand selectivity in industrial distribution channels. Journal of Marketing, 61(2), 19-34.

Frazier, G. L., \& Lassar, W. M. (1996). Determinant of distribution intensity. Journal of Marketing, 60(4), 39-51.

Frazier, G. L., \& Shervani, T. A. (1992). Multiple channels of distribution and their impact on retailing, in The Future of U.S. retailing: An agenda for the 21 st Century, Robert A. Peterson ed. Westport, CA: Quorum Books.

Frazierr, G. L., Gill, J. D., \& Kale, S. (1989). Dealer dependence levels and reciprocal actions in a channel of distribution in a developing country. Journal of Marketing, 53(1), 50-69.

Fripp, G. (2017). Utility in marketing. Retrieved from http://www.marketingstudyguide.com/utility-in-marketing/. [Accessed, 1/7/2017].

Geersbro, J., \& Vedel, M. (2008). Creating value through intermediaries. Paper presented at the Paper Prepared for the 24th IMP Conference, University of Uppsala, Sweden.

Gerdoci, B., Skreli, E., \& Imami, D. (2015). Relational governance: An examination of the apple sector in Albania. Journal of Central European Agriculture, 16(2), 72-88.

Gitobu, M. (2004). Determinants of distribution intensity among firms in the Kenyan pharmaceutical industry. Retrieved from http://erepository.uonbi.ac.ke. [Accessed, 9/6/2018].

Hassanzoy, N. (2013). Agricultural marketing for a small agribusiness: A training manual. Retrieved from https://www.academia.edu/8836587/Agricultural_Marketing_for_a_Small_Agribusine. [Accessed, 2/7/2017].

Hibbard, J., Kacker, M., \& Sadeh, F. (2017). Performance impact of distribution expansion: A review and research agenda. Retrieved from https://papers.ssrn.com/sol3/papers.cfm?abstract_id=3048998. [Accessed, 30/8/2018].

Holmstrom, B., \& Roberts, J. (1998). The boundaries of the firm revisited. Journal of Economic Perspectives, 12(4), 73-94. 
Homburg, C., Vollmayr, J., \& Hahn, A. (2014). Firm value creation through major channel expansions: Evidence from an event study in the United States, Germany, and China. Journal of Marketing, 78(3), 38-61.

Imam, Y. B., Chibok, B. M., \& Gamama, Y. (2014). Channel of distribution of agricultural produce in Nigeria. Journal of Biology, Agriculture and Healthcare, 4(22), 62-66.

Jindal, R. P., Reinartz, W., Krafft, M., \& Hoyer, W. D. (2007). Determinants of the variety of routes to market. International Journal of Research in Marketing. 24(1), 17-29.

Joskow, P. (1988). Asset specificity and the structure of vertical relationships: Empirical evidence. Journal of Law, Economics and Organisation, 4(1), 95-117.

Kaiser, H. F. (1974). An index of factorial simplicity. Psychometrika, 39(1), 31-36.

Kalubanga, M., Tumwebaze, S., \& Kakwezi, P. (2012). Examining the Effect of Multi-Channel Product Distribution on Firms' Performance. International Journal of Economics and Management Sciences, 1(12), 90-103.

Kotler, P., \& Keller, K. L. (2009). Marketing management (13th ed.). Upper Saddle River, New Jersey: Pearson Education, Inc.

Kotlers, P., Swee, A. H., Siew, L. M., \& Chin, T. T. (2003). Marketing management: An Asian perspective (3rd ed.). Singapore: Prentice Hall, Inc.

Krejcie, R. V., \& Morgan, D. W. (1970). Determining sample size for research activities. Educational and Psychological Measurement, 30(3), 607-610

Ladipo, P. K. A., Alarape, W. B., \& Nwagwu, K. O. (2013). Empirical determinants of the choice of intermediaries by selected multinationals operating in Nigeria’s food/drinks market. International Journal of Marketing Studies, 5(1), 134-141.

Liu, H. W., Huang, H. C., \& Lin, Y. L. (2009). Asymmetric effect of distribution intensity on marketing performance: The moderating role of brand awareness. Asia Pacific Management Review, 14(3), 251-262.

Liwali, K. (2013). Analysis of marketing channels for effective distribution of consumer products by small scale manufacturing enterprises in Zamfara State. Virtual Library, University of Nsuka.

Macklin, T. (1924). Efficient marketing for agriculture. New York: Macmillan.

Myers, J., Van Metre, E., \& Pickersgill, A. (2004). Steering customers to the right channels. The McKinsey Quarterly. Retrieved from http://www.mckinseyquarterly.com/Steering_customers_to_the _right_channels_1504. [Accessed, 30/8/2018].

National Bureau of Statistics. (2016). Retrieved from www.nigerianstat.gov.ng/. [Accessed 3/9/2018].

Neslin, S. A., Dhruv, G., Robert, L., Venkatesh, S., Marije, L. T., Jacquelyn, S. T., \& Peter, C. V. (2006). Challenges and opportunities in multichannel customer management. Journal of Service Research, 9(2), 95-112.

Noble, S., Shenkan, A. G., \& Shi, C. (2009). The promise of multichannel retailing. The McKinsey Quarterly. Retrieved from http://www.mckinseyquarterly. com/Marketing/Digital_Marketing/The_promise_of_multichannel _retailing_2448. [Accessed, 30/8/2018].

Nunes, P. F., \& Cespedes, F. V. (2003). The customer has escaped. Harvard Business Revierw, 81(11), 96-105.

Nunnally, J. C. (1978). Psychometric theory. New York: McGraw.

Obaji, R. N. (2011). The effects of channels of distribution on Nigerian product sales. International Business and Economics Research Journal, 10(2), 85-92.

Odupitan, A. T. (2017). Understanding the distribution channels of fast moving of consumable goog (FMCG) of food industry in Nigeria. Retrieved from https://www.theseus.fi/bitstream/handle/10024/138255/ODUPITAN_AMINAT.pdf? sequence=1. [Accessed, $30 / 4 / 2018]$.

Oko, A. E. N. (2013). Dis-intermediation and its effects (impacts) in the marketing of consumer products. A case of developing economy-Nigeria. Global Advanced Research Journal of Educational Research and Revierw, 2(5), 111-118.

Onyemah, V., \& Akpa, S. O. (2016). Open air markets: uniquenesses about African marketing channels. International Marketing Review, 33(1), 112-136.

Rangaswamy, A., \& Van Bruggen, G. H. (2005). Opportunities and challenges in multichannel marketing: An introduction to the special issue. Journal of Interactive Marketing, 19(2), 5-11.

Saraf, S. (2009). Intensity of market coverage. Retrieved from http://www.slideshare.net/abhilashsaraf/intensity-ofmarket-coverage. [Accessed, 8/6/2017].

Sarkar, D. N., \& Pareek, G. (2012). Wholesale model of rural distribution in FMCG: A quantitative study of factor. International Journal of Management Research and Reviews, 2(8), 1347-1353.

Stern, L., El-Ansary, A., \& Coughlan, A. (1996). Marketing channels (5th ed.). Upper Saddle Creek, NJ: Prentice-Hall Publishers.

Sule, J. a. G., Ogbadu, E., \& Achimugu, L. (2013). Channel Management for Household Products Companies in Nigeria. International Journal of Academic Research in Business and Social Sciences, 3(2), 37-45.

Valentini, S., Montaguti, E., \& Neslin, S. A. (2011). Decision process evolution in customer channel choice. Journal of Marketing, 75(6), 72-86.

Van Bruggen, G. H., Antia, K. D., Jap, S. D., Reinartz, W. J., \& Pallas, F. (2010). Managing marketing channel multiplicity. Journal of Service Research, 13(3), 331-340.

Wallace, D. W., Giese, J. L., \& Johnson, J. L. (2004). Customer retailer loyalty in the context of multiple channel strategies. Journal of Retailing, 80(4), 249-263.

Weinberg, B. D., Parise, S., \& Guinan, P. J. (2007). Multichannel marketing: Mindset and program development. Business Horizons, 50(5), 385-394.

Weld, L. D. H. (1916). The marketing of farm products. New York: Macmillan.

Williamson, O. E. (1979). Transaction-cost economics: The governance of contractual relations. The Journal of Law and Economics, 22(2), 233-261. 
Williamsone, O. (1975). Markets and hierarchies, analysis and antitrust implications: A study in the economics of internal organisation. New York: Free Press.

Williamsonn, O. E. (2005). The economics of governance. American Economic Review, 95(2), 1-18.

Williamsons, O. E. (2002). The theory of the firm as governance structure: From choice to contract. Journal of Economic Perspectives, 16(3), 171-195.

Williamsony, O. E. (1991). Comparative economic organization: The analysis of discrete structural alternatives. Administrative Science Quarterly, 36(2), 269-296.

Winsor, R. D., Sheth, J. N., \& Manolis, C. (2004). Differentiating goods and services retailing using form and possession utilities. Journal of Business Research, 57(3), 249-255.

Yoo, B., Donthu, N., \& Lee, S. (2000). An examination of selected marketing mix elements and brand equity. Journal of the Academy of Marketing Science, 28(2), 195-211.

Zikmund, R., \& d'Amico, T. P. (2011). Marketing action in networks. European Journal of Marketing, 4(11/12), 1271-1291. 